\title{
Density of mucosal mast cells in the lamina propria of the colon and terminal ileum of children
}

\author{
IR SANDERSON, ${ }^{*}$ G SLAVIN, $\dagger$ JA WALKER-SMITH* \\ From *the Laboratory for Paediatric Gastroenterology and the Department of Histopathology, \\ St Bartholomew's Hospital, London EC1
}

SUMMARY Ileal and colonic biopsies from children observed to be histologically normal were fixed in Carnoy's fluid, sectioned, and stained by the chloroacetate esterase reaction. The density of mucosal mast cells was higher in the terminal ileum than the colon, but did not vary significantly within the colon.

Mast cells from different organs may differ in their staining properties' and their function. ${ }^{2}$ Two main types of cell are recognised; connective tissue mast cells and mucosal mast cells. The role of the mast cell in the terminal ileum and colon is not known. This is partly because mast cells in the lamina propria are of the mucosal variety and therefore not stable when fixed in buffered formol-saline ${ }^{13}$; moreover, the normal range of mast cell numbers has not been established in histologically normal tissue in man. In the rat there are differences in the density of mucosal mast cells in different parts of the alimentary tract. ${ }^{4}$ In this study we have compared the density of mast cells in the terminal ileums and ascending and descending colons of children with histologically normal intestine. Rather than using electron microscopy, where only small areas of tissue can be inspected, intestinal biopsies were examined under light microscopy. They were fixed in Carnoy's solution to preserve the mucosal mast cells $^{1}$ and they were stained by the chloroacetate esterase method ${ }^{5}$ so that they could be easily seen.

\section{Material and methods}

\section{SUBJECTS}

Thirteen children aged 5 years 6 months to 15 years 2 months with symptoms of abdominal pain were admitted for colonoscopy to exclude chronic inflammatory bowel disease. All children were biopsied in the terminal $3 \mathrm{~cm}$ of ileum, ascending colon, and descending colon for routine histology. Sections fixed in formol-saline and stained with haematoxylin and eosin were within normal limits. The children were diagnosed as having normal gastrointestinal tracts when all investigations had been completed and no hitherto recognised abnormalities were found.

Accepted for publication 14 February 1985
FIXATION AND STAINING

Biopsies from tissue adjacent to that taken for routine histology were taken for fixation in Carnoy's fluid and were orientated flat on card. They were transferred into a mixture of chloroform and ethanol (1:1) after $20 \mathrm{~h}$. After being passed into chloroform they were embedded in paraffin wax and then sectioned at $5 \mu \mathrm{m}$.

The sections were stained by an enzymatic stain using the chloroacetoesterase activity of mast cell granules. They were incubated in pararosaniline and naphthol chloroacetate for a maximum of $15 \mathrm{~min}$ to avoid staining cells other than mast cells. They were then counterstained with haematoxylin (Table 1). Mast cell granules stain red and nuclei dark blue (Fig 1).

\section{MORPHOMETRY}

The total number of mast cells in the lamina propria of a section of each biopsy was counted. A tracing of the lamina propria was made using an Olympus BHB side arm at a magnification of $75 \times$ (Fig 2). Care was taken to exclude lymphoid nodules, epithelium, and muscularis mucosa. The irregular area of the lamina propria was measured by computerised image analysis. ${ }^{6}$ A Hewlett-Packard HP 2100 minicomputer was used with a digitilising table and a follower, which was run over the tracing. All measurements were repeated with an observer variation of less than 5\%. Mast cell density was expressed as number of cells per $\mathbf{m m}^{2}$ of lamina propria.

Mast cell densities of different areas of bowel were compared using one way analysis of variance and Student's $t$ test.

\section{Results}

Large areas of lamina propria were examined (Table 2 ); the mast cells were counted and their density 
Table 1 Chloroacetate esterase method

Preparation of solutions

(a) Substrate solution:

Naphthol AS-D chloroacetate

Dimethylformamide

(b) Buffer solution:

0.1 M Michaelis buffer. $\mathrm{pH}$ 6.8-7.6

(c) Pararosaniline-HC1 stock solution:

Pararosaniline hydrochloride

$2 \mathrm{~N} \mathrm{HC1}$

Heat gently until solid dissolves, cool to room temperature, and filter

(d) Sodium nitrite solution:

Sodium nitrite

Distilled water

(e) Hexazotised pararosaniline solution:

Pararosaniline-HC1 stock solution (c)

Sodium nitrite solution (d)

freshly prepared

Mix well, allow to stand for $30 \mathrm{~s}$ then use immediately
Preparation of incubating medium

To $0.8 \mathrm{~cm}^{3}$ of freshly prepared hexazotised pararosaniline solution (e), add

$10 \mathrm{mg}$

$30 \mathrm{~cm}^{3} \mathrm{U} \cdot 1 \mathrm{M}$ Michaelis butter solution (b), and adjust $\mathrm{pH}$ to 6.3 with $\mathrm{HC}$; then immediately add substrate solution (a). The resultant solution, which resembles pink milk, is filtered, and the clear pale pink filtrate is used as the incubating medium.

$30 \mathrm{~cm}^{3}$

$50 \mathrm{~cm}^{3}$

$400 \mathrm{mg}$

$10 \mathrm{~cm}^{3}$

$0.4 \mathrm{~cm}^{3}$

$0.4 \mathrm{~cm}^{3}$
Method

1 Paraffin sections to water.

2 Incubate sections in freshly prepared filtered incubating medium.

3 Rinse in water.

4 Counterstain nuclei in Mayer's haematoxylin.

$15 \mathrm{~min}$

5 Blue in Scott's tap water.

6 Rinse in water, dehydrate, clear and mount in DPX.

\section{Results}

Esterase activity - pinkish red.

Nuclei-blue-black. shown in the three different areas of the bowel (Fig 3). There was no significant difference in the density of mast cells between the two sides of the colon $(t=0.54, p>0.1)$. The density of mast cells in the terminal ileum, however, was significantly greater than that in either the left or right side of the colon ( $p<0.001)$ Examination of the whole section showed no mast cells in the epithelial layer or within Peyer's patches.

\section{Discussion}

Electron microscopy is a good way to recognise mast cells, but counting cells over a large area of the mucosa is not easy. With light microscopy whole sections of biopsies may be scanned. But a technique is needed that will fix the mast cells without destruction of granules and then allow them to be stained clearly. Studies using various fixatives in the examination of mast cells ${ }^{13}$ have specified Carnoy's as a good fixative. Direct stains such as alcian blue and astra blue have been advocated, but results have

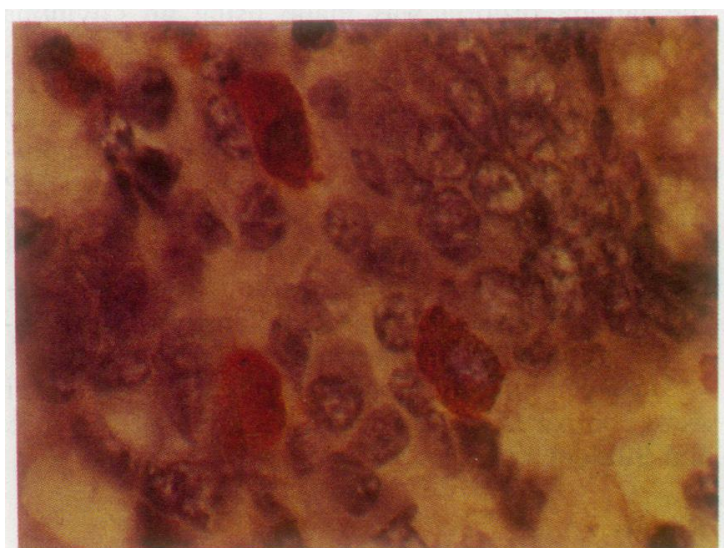

Fig. 1 Mucosal mast cells from lamina propria of the terminal ileum stained by the chloroacetate esterase reaction and counterstained with haematoxylin.

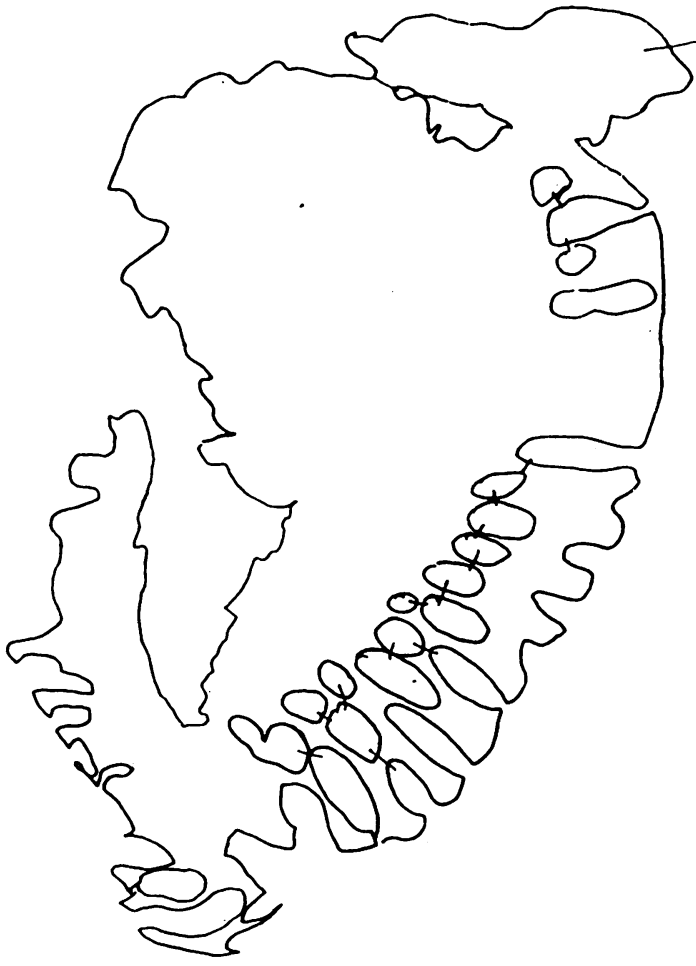

Fig. 2 Tracing of the lamina propria from a section of ascending colon.

Table 2 Area of lamina propria in sections examined $\left(\mathrm{mm}^{2}\right)$

\begin{tabular}{lll}
\hline & Mean & Range \\
\hline Terminal ileum & $0 \cdot 60$ & $0 \cdot 23-1 \cdot 04$ \\
Right colon & $0 \cdot 60$ & $0 \cdot 16-1 \cdot 90$ \\
Left colon & 0.93 & $0 \cdot 34-1 \cdot 84$ \\
\hline
\end{tabular}




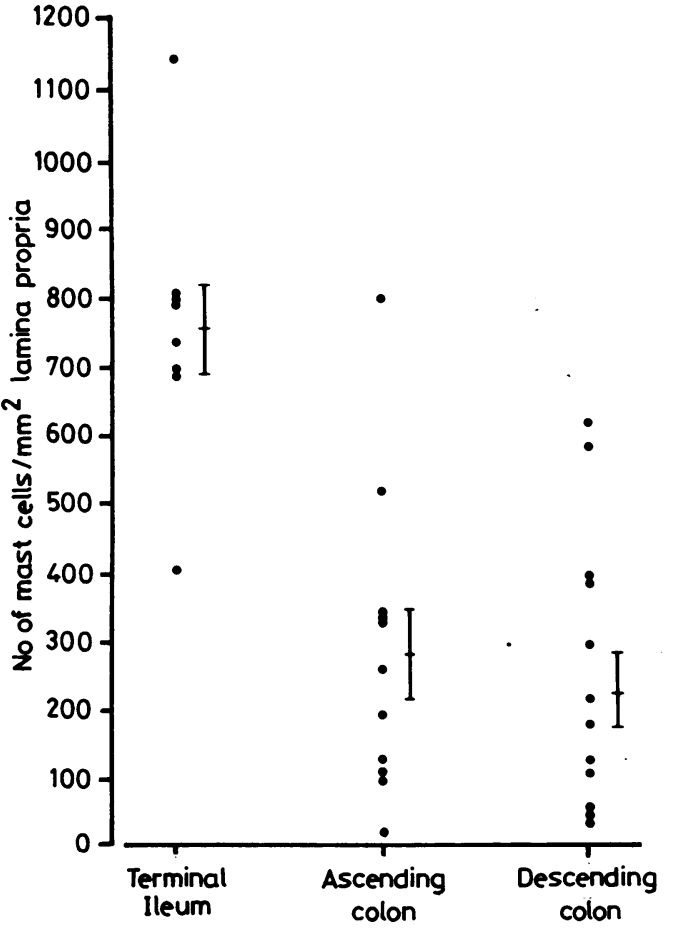

Fig. 3 Density of mucosal mast cells in different areas of the bowel (mean and standard error).

been variable depending on the batch of stain used. A stain dependent on the presence of an enzyme found in high activity in mast cell granules would be a suitable alternative. Chloroacetate esterase is such an enzyme.

Small amounts of this enzyme may also be found in the neutrophil series and these cells will therefore show as having a red cytoplasm if incubated for a long period. When the incubation is no longer than $15 \mathrm{~min}$, however, such cytoplasmic staining does not occur. Many sections containing neutrophils have been examined by us to establish this distinguishing feature. Macrophages contain non-specific esterase, but this enzyme does not catalyse the reaction when the sections are embedded in paraffin and differentiation from mast cells is not a problem.

The reason for the higher mast cell density in the ileum is not known. It may reflect a greater immunological role of the ileum. Two previous studies support this finding, although both were performed without reference to the heterogeneity of mast cells. Norries $\mathrm{et} \mathrm{al}^{7}$ investigated the gastrointestinal tract of a 30 year old woman, which had been fixed in lead acetate at necropsy, and found a higher mast cell density in the ileum than in other parts of the gut. It is not possible to compare those results directly with the present study because the authors expressed the area of lamina propria in terms of high power fields rather than absolute values. Lloyd et al, ${ }^{8}$ who stained adult bowel fixed in alcohol formalin after surgical resection, also showed significantly higher numbers of mast cells in the ileum than in the large intestine. The number of mast cells per unit area was smaller than that found in the present study, however, and this may reflect the use of a different fixative as well as possible age differences. Interestingly, detailed studies in the rat ${ }^{4}$ have also shown higher numbers of mucosal mast cells in the small intestine, but the difference is not as striking as in man.

The role of mast cells in disease is not understood. They may play a part in defence of the body to parasitic infestation. It is known that in the rat mucosal mast cell numbers increase greatly after helminth infestation. ${ }^{y}$ Their role in the inflammation of the bowel due to known aetiological agents such as rotavirus, enteropathogenic bacteria, and amoebae is not known; nor has it been determined in the idiopathic inflammation of chronic inflammatory bowel disease. The density of mast cells in these entities is under investigation, and the aim of this paper has been to establish a baseline.

Dr IR Sanderson is grateful for support from the Crohn's in Childhood Research Appeal.

\section{References}

' Enerbach L. Mast cell in rat gastrointestinal mucosa. Acta Pathol Microbiol Scand 1966;66:289-302.

${ }^{2}$ Pearce FL, Behrendt H, Blum U. Isolation and study of functional mast cells from lung and mesentery of a guinea pig. Agents Actions 1977; 7:45.

${ }^{3}$ Strobel S, Miller HPR, Ferguson A. Human intestinal mast cells: evaluation of fixation and staining techniques.J Clin Pathol 1981;34:851-8.

${ }^{4}$ Saavedra-Delgado AM, Metcalf D. The gastrointestinal mast cell in food allergy. Ann Allergy 1963;51:185-9.

${ }^{5}$ Leder LD. The chloroacetoesterase reaction. A useful means of histological diagnosis of haematological disorders from paraffin sections of skin. Am J Dermatopathol 1979;1:39-42.

- Maluenda C, Phillips AD, Briddon A, Walker-Smith JA. Quantitative analysis of small intestinal biopsy in Cow's milksensitive enteropathy. Journal of Pediatric Gastroenterology and Nutrition 1984;3:349-6.

' Norries HT, Zamcheck N, Gottlieb LS. The presence and distribution of mast cells in the human gastrointestinal tract at autopsy Gastroenterology 1963;44:448-55.

${ }^{8}$ Lloyd G, Green FHY, Fox H, Mani V, Turnberg LA. Mast cells and immunoglobulin $\mathrm{E}$ in inflammatory bowel disease. Gut 1975;16:861-6.

9 Miller HPR, Jarrett WFH. Immune reactions in mucous membranes. Intestinal mast cell response during helminth expulsion in the rat. Immunology 1971;20:277-88.

Requests for reprints to: Dr IR Sanderson, The Laboratory for Paediatric Gastroenterology, St Bartholomew's Hospital, London EC1, England. 